\title{
NOTES
}

\section{GIRLS DON'T JUST WANNA HAVE FUN: MOVING PAST TITLE IX'S CONTACT SPORTS EXCEPTION}

\author{
Jessica Constance Caggiano*
}

\begin{abstract}
I had to fight many battles being the only girl. These battles were not only physical but mental. When people told me that a girl should not play a man's sport, I took offense to it. I had just as much skill as they did and there was no reason why I should not have been out there. My work ethic and dedication was not more or less than the guys'.

It got hard when I started playing JV and Varsity hockey; the guys were getting bigger and stronger. It was sometimes hard to play against them because I knew I could possibly get hurt. But I just made sure I kept my head up and I was not going to let a guy stop me from playing the sport I love. All of this would make me work harder as well.

Both the physical and mental struggles I had to go through made me a stronger person because the mental side of it, when someone told me I shouldn't be playing a man's sport, it made me want to go out there and play harder and beat who ever said it. The physical part of it made me a stronger player. Playing now on a girl's [sic] team I am a very aggressive player. I tell myself that no one will beat me. If I can take a hit from a guy who is taller and weighs more then [sic] me, I will be able to take a hit from a girl my size.

If I could I would definitely do it again .... .

Angela Kost, on playing junior varsity and varsity ice hockey for Moon Area High School's Boys' Team. ${ }^{1}$
\end{abstract}

* I would like to thank Deborah L. Brake, Professor of Law, University of Pittsburgh School of Law for all of the feedback she provided throughout this process. It was very much appreciated. In addition, I would like to thank Angela Kost, who took time out of her own busy academic schedule to acquaint me with her athletic experience. I would also like to thank Sonia S. Shariff, Esquire, for her helpful comments, the University of Pittsburgh Law Review staff, and especially my family for supporting me.

1. Letter from Angela Kost to author (Jan. 4, 2009) (on file with the University of Pittsburgh Law Review). For more on Angela's successful ice hockey career, see http://www.collegehockeystats.net/0809/ 
Angela Kost's situation, while admirable, is not unique; many girls have played or currently play contact sports on boys' high school teams ${ }^{2}$ or on men's college teams. ${ }^{3}$ Others have possessed, and currently possess, not only the skills necessary to compete with men, but also the ability to achieve high levels of athletic success. ${ }^{4}$ Still, the current state of the law has deprived some female athletes of the opportunity to test their limits. ${ }^{5}$ It is for these athletes that we need to examine and, ultimately, change the laws currently affecting women's athletic opportunities.

It was not so long ago that much of society considered women physically incapable of running marathons without injury, ${ }^{6}$ let alone competent to compete with men in any sport - contact or non-contact. Today, such medical "certainties" have melted away as the gap between the women's and the men's marathon world record has narrowed to little more than ten minutes and barriers confronting female runners have disappeared. ${ }^{7}$ At the same time, many people currently believe that, although some exceptional women are able, the majority of female athletes cannot physically compete on the same

rosters/rmuw.

2. See CBC News, Winnipeg girls win right to play on boys' hockey team, http://www.cbc.ca/ canada/manitoba/story/2006/09/22/hockey-decision.html (last visited May 22, 2010); Matt Porter, Girls' Hockey Picking Up Steam: 92 High Schools Now Field Squads Across The State (Jan. 1, 2009), http://www.boston.com/sports/schools/hockey/articles/2009/01/01/girls_hockey_picking_up_steam_12 30667971/?page=1 (discussing how Denese Kerrissey became the first female to play in the boys' ice hockey state tournament in Massachusetts in the spring of 1992); Posting of Gretchen to Girls Can't Play Football, http://girlscantwhat.com/girls-cant-play-football/ (Mar. 20, 2007) (including many posted comments from high school girls playing football and other traditionally male-dominated sports on boys' teams). Ironically, the creator of the website requested that girls post their stories about playing on boys' teams, acknowledging how hard it is to search for this kind of information on the web by noting that "finding information about 'Girls Football [sic]' on the Internet has proved to be quite the challenge." Id.

3. See, e.g., A History of Girls Playing Tackle Football, http://www.fortunecity.com/wembley/ mueller/641/princesses/timeline.html (last visited May 22, 2010) (discussing the history of women playing on men's college football teams).

4. See, e.g., Mark Spezia, Goodrich's C.C. Weber Completes Wrestling Quadruple Crown, THE FLINT J., Aug. 3, 2008, available at http://blog.mlive.com/flintjournal/prepsnow/2008/08/goodrichs cc_weber_completes_wrestling_quadruple_c.html (discussing C.C. Weber, a two-time state qualifier in high school boys' wrestling and the first girl to win a match in the state tournament); Tim Twentyman, Goodrich's Weber Continues A Year of Firsts, The Detroit News, Mar. 9, 2007, available at http://www.wrestlegirl.com/gnews1823.htm (also discussing C.C. Weber's achievements).

5. See, e.g., ESPN.com, Report: Kicker Dismissed by Georgia Team for Being a Girl, (Aug. 31, 2008), http://sports.espn.go.com/ncaa/highschool/news/story?id=3560929.

6. Charlie Lovett, The Fight to Establish the Women's Race, in Olympic Marathon, available at http://www.marathonguide.com/history/olympicmarathons/chapter25.cfm.

7. See Marathon Records, http://www.marathonguide.com/history/records/ (last visited May 22, 2010). 
level as men in sports specifically contact sports. ${ }^{8}$ This way of thinking is well represented within the regulations of Title IX of the 1972 Education Amendments - the governing law for many public and private schools that receive federal funding. ${ }^{9}$ These regulations allow for sex-segregated athletic teams ${ }^{10}$ and include a contact sports exception (CSE) which provides that covered schools do not have to allow women to try out for men's contact sports teams. ${ }^{11}$

This note will discuss the aforementioned social perspective, along with other barriers to elimination, and justifications for maintaining the CSE. At their best, these impediments slow the progression of the law and the liberalization of society for female athletes. At their worst, they prevent the alteration or elimination of the $\mathrm{CSE}^{12}$ to Title IX. ${ }^{13}$ This evaluation will primarily analyze the possible justifications for promulgation of the CSE and ultimately recommend that Congress eliminate it. Finally, this note examines the consequences of removing the CSE and reviews other alternatives to the current law that would further liberalize our sex-segregated system of athletics.

Part I of this note will provide a general overview of Title IX, focusing on the CSE specifically, and will examine what its legislative history reveals about its purpose. In addition, Part I will also discuss the applicability of and the current rights of female athletes under the Fourteenth Amendment's Equal Protection Clause (EPC).

Part II will expand upon the possible purposes for the CSE addressed in Part I by identifying and analyzing other possible justifications. This section will ultimately recommend immediate elimination of the CSE and describe the state of the law post-elimination. However, removing the CSE will not eliminate the political and social issues surrounding it, or the ever-present concerns of many citizens about lawsuits involving Title IX and the Fourteenth Amendment's EPC. ${ }^{14}$ In fact, since many members of the public

8. See Dana Robinson, Comment, A League of Their Own: Do Women Want Sex-Segregated Sports?, 9 J. Contemp. Legal Issues 321, 346 (1998); see also, e.g., posting of Cody C. to SerendipUpdate's Blog, http://serendip.brynmawr.edu/exchange/node/1753?page=1 (Feb. 3, 2009, 22:01) (last visited May 22, 2010) ("I am not saying that some girls aren't as athletic as guys, but MOST aren't.") (representing a portion of the public's opinion on the subject).

9. See generally 20 U.S.C. $\S \S 1681-1688$ (2006) (authorizing the promulgation of regulations).

10. 34 C.F.R. $\S 106.41$ (b) (2006).

11. Id.

12. $I d$.

13. See generally 20 U.S.C. $\S \S 1681-1688$ (2006) (authorizing the promulgation of regulations).

14. See, e.g., Williams v. School Dist., 998 F.2d 168 (3d Cir. 1993) (challenging, on behalf of their 
accept the assumptions inherent in many CSE justifications, ${ }^{15}$ its elimination would likely spur public debate.

As such, Part III of this note will examine alternatives to Title IX's system of athletics that go beyond mere CSE elimination. This article will focus on analyzing the viability of a proposal that other authors have not substantially discussed $;^{16}$ a system of athletics that allows schools to use objective criteria, such as weight/height standards, in determining the eligibility of athletes to try out for the opposite sex's contact sports teams.

son, exclusion from girls' field hockey team under Title IX and the EPC; heavily criticized); Kleczek ex rel. Kleczek v. R.I. Interscholastic League, Inc., 768 F. Supp. 951 (D.R.I. 1991) (challenging denial of a spot on girls' field hockey team for a male student). Various blog posts also demonstrate the charged atmosphere surrounding Title IX. For instance, one individual stated, "Let's forget about gendered teams; there should be one-sport teams, and boys and girls should be allowed to play on them equally. Coed. None of this segregation." Posting of Anonymous to SerendipUpdate's Blog, http://serendip.brynmawr.edu/exchange/ node/1753 (May 2, 2009, 21:02) (last visited May 22, 2010). Another person emphatically stated, "IF A GIRL WANTS TO PLAY WITH A BOY IN A SPORT THEY SHOULD BE ALLOWED BECAUSE THEY GOT [sic] ALL THE RIGHTS THAT A MALE HAS. BUT I ALSO BELIEVE THAT A MALE COULD PARTICIPATED [sic] IN A FEMALE SPORTS THAT WAY EVERY THING [sic] COULD STAY EVEN.” Posting of Jose Angeles to SerendipUpdate's Blog, http://serendip.brynmawr.edu/exchange/ node/1753 (Apr. 23, 2009, 13:11) (last visited May 22, 2010).

15. See, e.g., Jonathan Little, Running Against the Wind: Sex Discrimination in High School Girl's Cross Country, 76 UMKC L. REv. 711, 716 (2008) ("While the argument of increased risk of injury to females may have merit in contact sports, such as football or rugby, this is not the case in non-contact sports, such as distance running ....") (emphasis added); Nishan Wilde, Women in Men's Sports-Should it be Allowed?, EzINE ARTICLES, http://ezinearticles.com/?Women-in-Mens-Sports-Should-it-beAllowed?\&id=621061 (last visited May 22, 2010) ("[W]hen it comes to contact sports, there are just too many issues and obstacles in the way. Not only are men at a psychological disadvantage because of our society's consensus towards gentle treatment of women, but also, women can often times find themselves in very compromising, even dangerous situations. Therefore, women in men's sports is not a good idea."). Similarly, another individual noted, "[O]kay [I] want to play football but ... my dad says it's a MAN sport and that girls should either be in the bleachers ir [sic] cheerleading EWWW i cannot belive [sic] i just said that word!' Posting of Jenny to SerendipUpdate's Blog, http://serendip.brynmawr.edu/exchange/node/1753 (July 15, 2009, 22:12) (last visited May 22, 2010) (representing a portion of the public's opinions on the subject).

16. See, e.g., Catherine Jean Archibald, De-Clothing Sex-Based Classifications-Same-Sex Marriage is Just the Beginning: Achieving Formal Sex Equality in the Modern Era, 36 N. Ky. L. REv. 1, 35 (2009) (arguing for sex integration, but that when "physical difference[s]" begin to separate males and females, "there are sex-neutral ways of dividing teams that will be fair to both men and women. . . . Similarly, all sports teams can be divided based on skill, weight, strength, or other sex-neutral characteristic[s]... [W] here a school used to have a boys' team and a girls' team, it could now have teams for people under a certain height or weight, and over a certain height or weight" (footnote omitted)); Aaron J. Hershtal, Does Title IX Work After School? California Applies the Three Part Test to Municipal Sports, 12 Cardozo J.L. \& Gender 653, 684 (2006) (referencing, briefly, that one court noted that "standards focusing on height, weight, or skill rather than solely on gender represents one such approach," but declined to go into detail). 
Despite the potential of some of these alternatives and the seeming propriety behind eliminating the CSE, Part IV will discuss the practicality of expecting any real change in the current regulations. Many authors at the time of writing their articles considered CSE elimination to be the eventual result, ${ }^{17}$ and yet the CSE remains intact, approximately 35 years after its implementation.

This note will conclude by briefly discussing ways to change the status quo, such as what society can do to begin to move past the CSE. Although some groups would inevitably suffer negative effects if the CSE were eliminated, ${ }^{18}$ to allow it to continue results in greater harm to both individuals and society as a whole.

\section{Part I. The Infamous Title IX}

\section{A. Title IX's Promulgation}

Congress passed Title IX as a part of the 1972 Education Amendments ${ }^{19}$ and although today it is best known publicly as a law affecting opportunities for women's sports, Congress' original intent and the language of the law itself was, and is, much broader: ${ }^{20}$ "No person in the United States shall, on the basis of sex, be excluded from participation in, be denied the benefits of, or be subjected to discrimination under any education program or activity receiving Federal financial assistance ...."

The Department of Education promulgated regulations for Title IX in 1975, including a section specifically explaining how it wanted the

17. See Blake J. Furman, Note, Gender Equality in High School Sports: Why There Is a Contact Sports Exemption to Title IX, Eliminating It, and a Proposal for the Future, 17 Fordham Intell. Prop. MEDIA \& ENT. L.J. 1169, 1187 (2007) ("Although abolishing the CSE is an appropriate starting point, its elimination is not a colossal leap forward. The concept that women should be able to try out for men's teams and be judged by their skill level is so basic to our understanding of discrimination that it is surprising that the CSE still exists." (footnote omitted)); Suzanne Sangree, Title IX and the Contact Sports Exemption: Gender Stereotypes in a Civil Rights Statute, 32 Conn. L. Rev. 381, 384-85 (2000) (speculating that the rising success and popularity of female sports would put pressure on public officials to change the law).

18. For example, qualified females displacing males on "male" contact sports teams.

19. 20 U.S.C. $\S \S 1681-1688$ (2006).

20. See id.; see also H.R. ReP. No. 92-554, at 5, 51-52, 108-09 (1971) (discussing both concerns about women's opportunities with regard to enrollment in colleges and the need to protect teachers and staff of educational institutions from sex discrimination, as they were not covered by Title VII; however, notably absent is any specific language expressing concern for women's opportunities in sports in contrast to public perception about exactly what the law does).

21. 20 U.S.C. $\S 1681$ (a) (2006). 
aforementioned language interpreted and applied with regard to athletics. ${ }^{22}$ The law's language generally prohibits covered entities from discriminating on the basis of sex and from excluding persons from participating in "any interscholastic, intercollegiate, club or intramural athletics on the basis of sex." ${ }^{23}$

Despite the broadness of the general rule, an exception is described for team segregation based on sex. ${ }^{24}$ However, separate must mean equal opportunity, at the least. ${ }^{25}$ The Department of Education's regulations list several factors to be considered by a court evaluating whether a covered entity has complied. These factors include the quality and provision of sporting equipment among separate teams, travel allowances and opportunities, the accommodation of individual abilities and interests, and the availability of a practice field or other areas, to name a few. ${ }^{26}$

On its face, this "separate but equal" solution seems practicable $;{ }^{27}$ however, many of the affected, covered entities are public schools and universities that could encounter financial difficulties complying. This lack of resources could result in the inability of a school to provide both a men's and a women's team for a particular sport where a school may have, traditionally, only provided a sports team for one particular sex. ${ }^{28}$ However, if a school has a sports team for one sex and not for the other, and opportunities for that sex have "previously been limited," the individual deprived of a team has a right to try out for a position on the opposite sex's existing team. ${ }^{29}$

Although perhaps fair on its face, the regulation does not stop there. The right to try out for the opposite sex's team evaporates under Title IX if the sport happens to be one the regulations designate as a "contact sport":

22. 34 C.F.R. $\S 106.41(2000)$.

23. $I d$.

24. $I d$.

25. 34 C.F.R. $\S 106.41(\mathrm{c})(2000)$

26. $I d$.

27. The debate on whether separate can be equal did not end with Brown v. Board of Education, 347 U.S. 483 (1954). See United States v. Virginia, 518 U.S. 515 (1996) (discussing whether Virginia's offer to create a similar women's military college would remedy its equal protection violation); see also infra note 83 (describing the current debate on sex-separated schooling).

28. This note does not pretend to address a school's liability under Title IX in such a situation. A school may have an obligation under the law to provide female athletes with a girls' sports team if the requisite level of interest is present. However, that is not the focus of this note, which merely uses it as an example of a situation in which there might only be a boys' team or a girls' team, but at least one interested female or male athlete to discuss the school's obligations with regard to letting her or him try out for the opposite sex's team.

29. 34 C.F.R. $\S 106.41(b)(2000)$. 
[A] recipient may operate or sponsor separate teams for members of each sex where selection for such teams is based upon competitive skill or the activity involved is a contact sport. However, where a recipient operates or sponsors a team in a particular sport for members of one sex but operates or sponsors no such team for members of the other sex, and athletic opportunities for members of that sex have previously been limited, members of the excluded sex must be allowed to try-out for the team offered unless the sport involved is a contact sport. For the purposes of this part, contact sports include boxing, wrestling, rugby, ice hockey, football, basketball and other sports the purpose or major activity of which involves bodily contact. ${ }^{30}$

The ability of a girl to play a contact sport on a boys' team is solely within the discretion of the covered entity - at the high school level, usually a school district - as is the initial right to try out for the team at all. ${ }^{31}$ The school district may deny her an opportunity to try out regardless of her individual capacity or talent, and solely because of her sex. ${ }^{32}$

\section{B. Equal Protection Clause Options}

A girl's right to try out for a boys' contact sports team under the Fourteenth Amendment's EPC is both broader and narrower than what Title IX's CSE encompasses. It is broader in that most courts have consistently held that public institutions may not preclude female athletes from trying out for boy's contact sports teams. ${ }^{33}$ However, it is narrower in that affected female athletes may only bring suit under the EPC against a public institution. In contrast, private institutions, many of which are Title IX entities because they

30. Id. (emphasis added).

31. See Mercer v. Duke Univ., 190 F.3d 643, 647-48 (4th Cir. 1999) (Discussing the post-hoc consequences of a university's decision to exercise its right to voluntarily allow members of the opposite sex on to a contact sport team under Title IX. In this case, Duke University initially allowed Heather Mercer to join the men's college football team.).

32. See 34 C.F.R. $\S 106.41$ (b) (2000) ("[M] embers of the excluded sex must be allowed to try-out for the team offered unless the sport involved is a contact sport.") (emphasis added). There is a right to a try-out that disappears if the sport is a contact sport, but there is no language prohibiting a covered entity from permitting her to try-out; hence the existence of girls currently playing on boys' contact sports teams. See generally Mercer, 190 F.3d at 647-48.

33. See, e.g., Adams ex rel. Adams v. Baker, 919 F. Supp. 1496, 1505 (D. Kan. 1996) (holding plaintiff was likely to succeed on the merits of her equal protection claim; school could not preclude female student from joining boy's wrestling team); Lantz ex rel. Lantz v. Ambach, 620 F. Supp. 663 (S.D.N.Y. 1985) (enjoining school district from preventing female athlete from trying out for boys' football team as a matter of equal protection); Leffel v. Wis. Interscholastic Athletic Ass'n, 444 F. Supp. 1117 (E.D. Wis. 1978) (holding plaintiffs' constitutional rights were violated by athletic association's rule preventing them from trying out for boy's sports teams). 
accept some form of federal funding, are free to prevent girls from even trying out for boys' contact sports teams. ${ }^{34}$

More specifically, since the Supreme Court's decision in United States v. Virginia, girls arguably have a right to try out for the boys' team even when a girls' team already exists. ${ }^{35}$ The majority of courts have declined to similarly allow men to try out for women's sports teams, even when the school has no such team for males. ${ }^{36}$

Although courts have held that girls have a constitutional right to try out for boys' teams, the CSE remains a stopper on the rights of female athletes for several reasons. Title IX's regulations technically apply to any institution that accepts federal dollars because the Supreme Court has never found the CSE to be unconstitutional. Thus, the CSE still governs the conduct of public institutions; the burden is then on the female athlete to enforce her rights under the EPC by filing suit. ${ }^{37}$ Also a concern, the Supreme Court's political balance has shifted since Virginia was decided. ${ }^{38}$ Regardless, the EPC does not help female athletes at private institutions covered by Title IX at all. CSE applies to private, Title IX entities in full force and thus, remains a formidable opponent to female athletes. ${ }^{39}$

34. 20 U.S.C. $\S 1681$ (a) (2006).

35. The Supreme Court's decision in Virginia would seem to compel this result, as Justice Ginsburg wrote that even if there were a "parallel" women's military institute, its existence would not necessarily, and did not in this case, remedy the constitutional violation. United States v. Virginia, 518 U.S. at 547-57; Jamal Greene, Hands Off Policy: Equal Protection and the Contact Sports Exemption of Title IX, $11 \mathrm{MIcH}$. J. GENDER \& L. 133, 144 (2005) (noting that Virginia elevated the standard for meeting an "excessively persuasive justification" under the intermediate scrutiny test). But see, e.g., Leffel, 444 F. Supp. at 1121 (holding that when a girls' team was already provided, female athletes did not have a constitutional right to try out for a boys' contact sports team just because the competition was allegedly better; noting that the association's failure to provide a sufficiently comparable female team might give a female the right to try out for the boys' team where a girls' team already exists).

36. See, e.g., Clark v. Ariz. Interscholastic Ass'n, 695 F.2d 1126 (9th Cir. 1982) (holding that excluding boys from playing on girls' volleyball teams was not a violation of the equal protection clause because the policy's purpose was to promote opportunities for girls and to remedy past discrimination); Kleczek ex rel. Kleczek v. R.I. Interscholastic League, Inc., 768 F. Supp. 951, 956 (D.R.I. 1991) (denying injunctive relief, in part, because plaintiff was unlikely to be successful on the merits of his Equal Protection claim where excluding male student from girl's field hockey team was unlikely to be a violation of the Equal Protection Clause).

37. See also Archibald, supra note 16, at 5-9 (2009) (noting critically that intermediate scrutiny, instead of strict scrutiny is applied to sex-based classifications in Equal Protection cases).

38. See Robert Barnes, Supreme Court Leans Conservative, WASH. Post, June 25, 2007, available at http://www.washingtonpost.com/wp-dyn/content/article/2007/06/25/AR2007062501047.html.

39. See generally Deborah Brake, The Struggle for Sex Equality in Sport and the Theory Behind Title IX, 34 U. Mich. J.L. Reform 13, 144 (2001) ("Moreover, the contact sports exemption remains a powerful contributor to the ideology of male dominance and superiority in sports."). 


\section{The CSE's Roots}

One might initially assume that the inclusion of the CSE in the regulations was a statutory mandate, or at least heavily debated among legislators. However, just as Title IX's specific effect on women's athletic opportunities was not heavily discussed or even anticipated, ${ }^{40}$ the CSE was not either. ${ }^{41}$ The closest evidence of Congressional intent for the CSE is the socalled Javits Amendment. This Amendment resulted when heavy lobbying efforts by the NCAA and attempts by Senator John Tower, R-Tex, at passing an amendment to protect revenue sports failed. The Javits Amendment "directed the Secretary of Health, Education and Welfare (HEW) to implement regulations for intercollegiate athletics with 'reasonable provisions considering the nature of particular sports." ${ }^{42}$ HEW proposed the initial regulations, which did not include the CSE. ${ }^{43}$ After the comment period for HEW's first set of proposed regulations had passed, the CSE was proposed and became part of the law in $1975 .^{44}$

Because of its ambiguity, one reasonable interpretation of the legislative and administrative history of the CSE is that HEW included it in the regulations to protect men's revenue sports from Title IX's effects. The NCAA's concerns and its lobbying efforts to protect big "money-makers" like college football and basketball may have led to the ambiguous language that accompanied the 1974 directive to HEW to promulgate regulations for Title IX generally. ${ }^{45}$ That directive gave HEW the authority to promulgate regulations for "reasonable provisions considering the nature of particular sports." 46

40. See 20 U.S.C. $\S \S 1681-1688$.

41. See Sangree, supra note 17, at 387 ("Contact sports are nowhere mentioned in Title IX or in its legislative history. Indeed, the statute's application to athletics was barely mentioned before it was enacted in 1972.").

42. Furman, supra note 17, at 1172 (citing Education Amendments of 1974, Pub. L. No. 93-380, 88 Stat. 484, 612 (1974) (codified as 20 U.S.C. $§ 1681$ (1994)).

43. Sangree, supra note 17, at 387.

44. Sangree, supra note 17, at 387-88 (citing 34 C.F.R. $§ 106.41$ (1998)).

45. See B. Glenn George, Fifty/Fifty: Ending Sex Segregation in School Sports, 63 Оніо Sт. L.J. 1107,1129 (2002) (arguing that the NCAA's influence is why basketball, the nature of which is arguably not physical contact, was included with other contact sports in the CSE's language).

46. Education Amendments of 1974, Pub. L. No. 93-380, 88 Stat. 484, 612 (1974) (codified as 20 U.S.C. § 1681 (1994)); Furman, supra note 17, at 1172; see also 34 C.F.R. $\$ 106.41$; Cohen v. Brown Univ., 101 F.3d 155, 165 n.5 (1st Cir. 1996) ("The regulations and agency documents discussed herein were originally promulgated by $\mathrm{HEW}$, the administering agency at the time, and later adopted by the present 
Subsequently, HEW issued a policy interpretation in 1979 in which it clarified that a school may have an obligation to create an equivalent female team if females had been historically disadvantaged in a particular activity or sport, there was sufficient female interest to sustain a team, and interested females had the ability to play the game. ${ }^{47}$ To some, this may appear to mitigate the harshness of the CSE, but it also reaffirmed the CSE's applicability. Where a female athlete is unable to rally such support, she may be left unable to participate in the sport at all.

Although the NCAA's interest in lobbying for a revenue sports exclusion is self-evident, it is far from certain that its interference resulted in the CSE's promulgation. An examination and understanding of other justifications for the CSE is helpful in analyzing whether or not there is a legitimate basis for it. This note will consider justifications for the CSE that have been suggested by courts, school districts, scholars, and other parties.

\section{Part II. The Reasons They Stand Behind and the Reasons That Hide Behind Them-Does the CSE Make Sense?}

\section{A. Is Protectionism Behind the CSE?}

Many scholars find it easy to conclude that the CSE is unnecessarily discriminatory and unjustified, ${ }^{48}$ and yet much of society finds the line drawn by the CSE to be not just fathomable, but the only natural result. ${ }^{49}$ Why does it sound natural, normal, and even logical to separate girls and boys from playing physical sports together? The danger of the CSE, and perhaps its longlife span, can be attributed in part to its apparent logic on the surface. It is only by delving deeper through a healthy critique of all possible justifications that society can begin to examine what legitimacy, if any, this social norm truly contains and whether it is worth maintaining the status quo.

\footnotetext{
administering agency, DED.”).

47. Furman, supra note 17, at 1175-76.

48. See id. at 1187.

49. See, e.g., supra note 15. This next individual commented on an article discussing co-ed possibilities and stated that "girls shouldn't be able to play with us men. [T] hey'll get their heads taken off easily. I am 14 and I play hockey and lacrosse and if girls played, THEY WOULD DIE!!! GO MEN!!" Posting of Anonymous to SerendipUpdate's Blog, http://serendip.brynmawr.edu/exchange/node/ 1753?page $=2$ (May 2, 2008, 14:09) (last visited May 22, 2010). Granted this is an exaggerated example, mostly added for humor, but it does tend to show how children are socialized with regard to this issue at a young age. This could also explain why, even as adults, many people still have lingering doubts about women and men playing together.
} 
Some members of the public might exclaim that the idea of a girl boxing with boys is ridiculous and could make some less-than-complimentary comments about "man-hating feminists" and "drugged-out liberal hippies." While it is unfair to attribute such a reaction to much of society, it is not uncommon for people to somehow feel that the idea of a boy boxing a girl is unnatural. ${ }^{51}$

This gut feeling of abnormality stems, for some, from long-held stereotypes about the inherent weakness of the female body and corresponding urges to protect the weak from harm in the form of protectionism. ${ }^{52}$ This note does not necessarily concede that, as a group, men are necessarily physiologically superior, noting and considering the following:

\begin{abstract}
It seems safe to say that, in most forms of direct athletic competition, males will generally defeat females. This verifiable conclusion might seem to indicate that physiological differences alone are responsible for the disparity in athletic performance. This conclusion is not as easily substantiated, however, as other factors may be involved. For example, male dominance in endurance sports such as longdistance running, soccer, and swimming may be due primarily to the newness of such sports (and sports in general) to women; indeed, studies demonstrate that women have the capacity for greater endurance and stamina than men. The competitive advantage of males over females in these sports, then, maybe solely attributable to the longer history of male participation rather than to any physical advantage. ${ }^{53}$
\end{abstract}

Nevertheless, protectionist thought processes lead to various assumptions including, independent of scientific studies on the subject, that men are just too fast and strong for women to rival. ${ }^{54}$ Logically then, the mind might move to concluding that women should not play with men for various reasons:

50. In fact, the author of this note knows and faithfully argues with a few people who hold these views.

51. See, e.g., supra notes 15,49 . Similarly, this next person noted, "I would be wondering why she [a girl who wants to play football] doesn't want to do what the other girls are doing, perhaps cheerleading. Why is she so motivated to stand out in a tom-boyish fashion? If there were such a thing as an all girls [sic] team, maybe it would be acceptable. But even then, a girl is being groomed, by the nature of the game, for a 'road construction' mind set rather than the softer, more feminine roles appreciated by society." Posting of mrazzip to InfoSports: Girls in Football, http://www.infosports.com/football/arch/2378.htm (last visited May 22, 2010).

52. See Robinson, supra note 8 , at 350 (addressing briefly an argument forwarded by many that women will be more easily injured and conceding this position regarding football and rugby).

53. Virginia P. Croudace \& Steven A. Desmarais, Where the Boys Are: Can Separate Be Equal in School Sports?, 58 S. CAL. L. Rev. 1425, 1446-47 (1985) (citing Attorney Gen. v. Mass. Interscholastic Athletic Ass'n, 393 N.E.2d 284, 293 n.34 (Supreme Judicial Ct. of Mass., Suffolk 1979) (discussing different athletic attributes of each sex)).

54. Robinson, supra note 8, at 346 (arguing against allowing these types of assumptions to guide the discussion on the eligibility of specific women to compete). 
because they slow down the pace of the game for men or spoil the quality of the competition; because women are not serious enough about sports; because women are not aggressive or competitive enough; or because women are too likely to get hurt playing with physically superior athletes. Why should men have to worry about injuring women when they are trying to enjoy the game, right? One might then conclude that the cost of allowing women to play with men outweighs the benefit.

While it is uncertain what exactly the drafters of the CSE had in mind, these types of protectionist generalizations about women as a group have something in common with the CSE. Both the CSE and the minds of some members of society have simplified this complex issue by generalizing about women as a group. The inherent flaw in both is a propensity to lump men and women into two separate spheres of athletic ability and judge all members of each sphere the same.

\section{B. Is the Possibility of an Increased Risk of Injury for Female Athletes a Legitimate Justification or Just Protectionism in Disguise?}

From protectionism, ${ }^{55}$ one could argue, comes the belief that girls are more likely to get injured playing sports of any kind, ${ }^{56}$ with that risk becoming even greater when girls play contact sports with boys.$^{57}$ Ironically, despite the fact that many scholars believe that the notion is archaic and out-of-date, safety concerns are sometimes the openly-admitted reason for persons supporting application of the CSE.$^{58}$ Although scholars have reason to doubt the persistence of such seemingly archaic beliefs, there is reason to fear that may not be the case. ${ }^{59}$ "While the argument of increased risk of injury to females may have merit in contact sports, such as football or rugby, this is not

55. See Furman, supra note 17, at 1181-82.

56. See, e.g., Little, supra note 15, at 717 ("By not allowing females to run the full 5,000 meter distance, state athletic associations, particularly the KHSAA, believe they are protecting female distance runners from the increased likelihood of injury and illness that would result if young women were allowed to run that distance.").

57. See Croudace \& Desmarais, supra note 53, at 1441-42; see also Furman, supra note 17, at 1181-82 (critically analyzing this belief).

58. See George, supra note 45, at 1129; Robinson, supra note 8, at 346; Sangree, supra note 17, at 417-18; 421-30 (indicating that safety emerged as a justifying factor for the CSE and also discussing various cases where protecting females from injury was used as a defense).

59. In Phillips v. Anderson County Bd. of Educ., No. 3:06-CV-35, 2006 WL 3759893, *9 (E.D. Tenn. Dec. 19, 2006), the female plaintiff was admittedly taken out of an otherwise all male lifting and conditioning class because her teacher believed removal would protect her from the risk of rape and sexual assault. 
the case in non-contact sports, such as distance running, where there are no major differences in the risk of injury between male and female runners." ${ }^{90}$ Protectionism not only encompasses the "injury" justification, but swallows up the arguments of those who would keep women from playing contact sports because of the supposed specific risk it places on their reproductive organs. ${ }^{61}$

However, labeling those concerned with the risk of injury as protectionist may not be entirely fair. The belief that girls are at a higher risk of injury when playing with boys does not have to be grounded in protectionist fantasies and notions about the inherent weakness of a woman's body. School districts could and have made strong arguments that the relative average sizes of the sexes, when looking at height and weight averages or similar objective factors, ${ }^{62}$ for example, justifies a fear for the safety of women and complete segregation between men's and women's contact sports. ${ }^{63}$

Although the logic behind the injury justification seems facially appealing, there are many problems with it. While it may be the most convincing of the various possible justifications for the CSE, the injury justification is not a sufficient reason for keeping the CSE. At best, the injury justification is a mere consideration in the later discussion of alternatives to the current sex-segregated system of athletics.

The main problem with separating men and women because of safety concerns is that school districts compare women as a group to men as a group in determining who is at greater risk for injury. This is analogous to the way

60. Little, supra note 15 , at 716.

61. See Furman, supra note 17, at 1182.

62. See, e.g., Lantz ex rel. Lantz v. Ambach, 620 F. Supp. 663, 665 (S.D.N.Y. 1985) ("Here the governmental objective is to protect the health and safety of female students, and there is no quarrel with the importance of that objective. To demonstrate that the regulation is substantially related to that objective, the Commissioner and the Board of Regents have offered data establishing that 'as a general rule, senior high school students (age 15 through 18) are more physically developed, stronger, more agile, faster and have greater muscular endurance than their female counterparts' (Att'y Genl's brief at 6-18), medical opposition to girls' participation on boys' teams in such contact sports as football (which Dr. Falls described as a 'collision' sport) because of the risk of injury in such participation, and the testimony of Dr. Willie to the effect, among other points, that the present regulation enhances safety by permitting simple and uniform administration across the state.").

63. See, e.g., Adams ex rel. Adams v. Baker, 919 F. Supp. 1496, 1504 (D. Kan. 1996) (noting, in the context of an Equal Protection challenge to a student's preclusion from playing on a boys' team, that safety is an important governmental objective; nevertheless, granting plaintiff's request for injunctive relief because school district's interest in student safety was not sufficiently related to its policy of excluding all females from trying out for men's contact sports teams). Adams exemplifies cases brought under Title IX and the Equal Protection Clause in which a court disallowed a member of one sex to play on the opposite sex's team based on safety concerns, not from a sense of protectionism, but from an ostensible realistic assessment about the average height and weight differences between the sexes. 
in which many people's protectionist preconceptions generalize. Even if it were true that women as a group are more likely to get injured based on an assessment of the average high school girl's height and weight being less than the average boy's, ${ }^{64}$ sex-segregation, because of safety concerns, still completely ignores the needs of the individual, as it excludes all persons in the group based on a group statistic at the individual's expense. Even if this note concludes that the CSE should give way to individual opportunities to try out for opposite-sex sports teams, should internal statutory limitations on female athletic opportunities within Title IX reasonably be interpreted on an individual, as opposed to a group, basis?

\section{Increased Risk of Injury as an Exclusion for Some Individual Girls (and Some Boys), Not Girls as a Group under Title IX}

Title IX incorporates several different aspects of feminist theory, ${ }^{65}$ but arguably much of the statute is based on a "differences" feminist theory. In that sense, Title X's purpose can be understood as protecting the opportunities of women as a group, not as individuals. ${ }^{66}$ Thus, applying the CSE-itself an internal limitation on Title IX's expansion of opportunities for women - to all women as a group does not seem odd at first blush. Despite this, a stronger argument supports viewing women as individuals, not as a group, when sections of Title IX - such as the CSE or a reasonable modification of it - operate to limit their athletic opportunities.

The reason Title IX can be viewed as incorporating a "differences" feminist theory is because its congressional purpose is to benefit women as a group and to increase participation in athletics by women as a group. ${ }^{67}$ Since increasing the participation and opportunities of women in sports is one goal of the statute, the courts and the Department of Education should not interpret

64. See supra note 61. That is, assuming height and weight are factors that have been shown to affect safety in sports. Courts and scholars have acknowledged the supposed link between size and safety. See also, e.g., Petrie v. Ill. High Sch. Athletic Ass'n, 394 N.E.2d 855, 862 (Ill. Ct. App. 1979); Adam S. Daroski, Comment, For Kenny, Who Wanted to Play Women's Field Hockey, 12 Duke J. Gender L. \& POL'y 153, 158 (2005) (linking size to safety).

65. See generally Deborah Brake, Title IX as Pragmatic Feminism, 55 Clev. St. L. Rev. 513 (2007) (discussing how the representation of different types of feminist ideology present in Title IX, combining as a more pragmatic feminism, is one of its strengths).

66. See Equity in Athletics Inc. v. U.S. Dept. of Educ., 291 Fed. Appx. 517, 523 (4th Cir. 2008) (citing a litany of case law describing the goals of Title IX as equalizing opportunities between men and women as groups, stating required program expansion for the underrepresented sex is one goal of the statute).

67. See generally id. 
limitations on athletic opportunities in a way that frustrates that purpose. ${ }^{68}$ Thus, the CSE's exclusion of women as a group from a wider array of athletic opportunity can also reasonably be understood as frustrating one of the main purposes of Title IX itself.

Even if one lends credence to the increased-risk-of-injury-for-women justification, the CSE is overbroad in that it precludes more women than is necessary from participating in men's sports to accomplish a goal of protecting women from supposed greater risk of injury. ${ }^{69}$ This is because there are, of course, women of varying height and weight combinations, some of whom would be at no greater risk than men in competition. Certain women would not be at any increased risk, or would possess less of a risk than the group average. Thus, the justification would not apply to these women with equal force and the risk of injury could not logically be used to keep them from trying out. Even if increased risk of injury were a legitimate reason for the CSE, these women are truly precluded because of their sex alone.

\section{Even If Individually Analyzed, Increased Risk of Injury as an Alternative Bar Still Poses Problems}

The increased-risk-of-injury justification as a limitation on female athletes is only truly legitimate if school districts apply their safety justification to male and female athletes equally. To the extent that school districts do not equally enforce some sort of safety standard, it is a discriminatory and protectionist practice to impose that will on smaller, possibly weaker-than-average females and not on smaller and possibly weaker-than-average males. ${ }^{70}$ Why should a school district be concerned about its average-sized female students getting injured while trying out for the football team with larger-than-average males when they are not concerned for

68. See Fed. Election Comm'n v. Democratic Senatorial Campaign Comm'n, 454 U.S. 27, 32 (1981) (“[Courts] must reject administrative constructions of the statute, whether reached by adjudication or by rulemaking, that are inconsistent with the statutory mandate or that frustrateunder represented Congress sought to implement.").

69. See, e.g., Adams ex rel. Adams v. Baker, 919 F. Supp. 1496, 1504 (D. Kan. 1996) (granting injunctive relief under EPC to female athlete because school's safety policy preventing women from competing on men's wrestling team was, "not substantially related to that objective. The defendants' only evidence that plaintiff's safety is at greater risk because of her gender is based on generalized assumptions about the differences between males and females regarding physical strength. The evidence shows that some females are stronger than some males. The school can take into account differences of size, strength, and experience without assuming those qualities based on gender." (internal citations omitted)).

70. See Archibald, supra note 16, at 35-36 (in agreement). 
similarly-situated male students? The male is often allowed to try out for America's high school football teams whereas the female is precluded on protectionist bases; even more, school districts often attempt to justify their conduct by pointing to the safety justification. ${ }^{71}$

In fact, it seems unlikely that safety for women could be the true reason behind CSE support, as a recent study shows that cheerleading, which many schools support as a "girls" sport, is the most high-risk sport for girls. ${ }^{72}$ However, cheerleading for girls flourishes as a sport among school districts, further supporting the point that it is not really a concern for safety that schools have in mind.

Although at first glance this reasoning seemed promising, the injury or safety justification reveals that it is not a legitimate justification, but rather a discriminatory and protectionist one. Where young males subject to greater risk of injury are allowed to decide whether to encounter that risk themselves, young females, being of equal intelligence, are just as qualified to decide for themselves.

\section{E. The Contact Sports Exception Should Be Eliminated}

If scientific evidence shows that increased risk of injury is a legitimate concern for some athletes and a school district imposes a safety limitation on all affected athletes, not just female athletes, such a policy might serve to legitimately limit the opportunities of some female and male athletes alike. However, the CSE does not operate as just described and so neither this justification nor other protectionist justifications and generalizations about women are legitimate reasons for maintaining the current regulation.

After examining the most promising justifications for maintaining the CSE, this note advocates immediate elimination. Even if pseudo-legitimate justifications, such as safety, were not actually the motivating factors behind CSE implementation, then possible unstated justifications such as male

71. See, e.g., Adams, 919 F. Supp. 1496 (noting, in the context of an equal protection challenge to a student's preclusion from playing on a boys' team, that safety is an important governmental objective).

72. See LiveScience Staff, The Most Dangerous Female Sport: Cheerleading, Live Science, June 26, 2009, available at http://www.livescience.com/health/090626-cheerleading-injuries.html. 
domination theory ${ }^{73}$ or the NCAA's lobbying interests ${ }^{74}$ certainly do not come close to legitimizing the exception.

Without the CSE, the rights afforded to female athletes under Title IX are still slightly different than their rights under the EPC. The pertinent Title IX regulation, less the CSE, reads that a girl must be allowed to try out for a boys' sports team where there is no girls' team; it does not necessarily permit a girl to try out for a boys' soccer team, for example, when the school already has a girls' soccer team. ${ }^{75}$ Contrast this, to the Supreme Court's interpretation of the EPC in Virginia, which may stand for the proposition that providing females with a comparable sports team does not necessarily cure an equal protection violation. ${ }^{76}$ Even without the CSE, Title IX is arguably more restrictive than the EPC. Should Title IX be brought in line with the EPC? Some scholars question the sex-segregated system itself, and still others question the fairness of allowing girls to try out for boys' teams ${ }^{77}$ when courts have not permitted the reverse - even when there is no boys' team on which a male athlete could play. ${ }^{78}$

Although CSE elimination would be an improvement, many concerns about our system of student athletics remain, and academics and courts alike debate them to this day. However, elimination of the CSE would likely

73. Furman, supra note 17, at 1180-81 ("In response to the feminist movement, organized sports were developed as a domain that 'emphasized physical strength, competition, and violence.' . . Men were threatened by the newfound success of the female community and sought new ways for society to place greater emphasis on their attributes." (footnotes omitted)).

74. See Furman, supra note 17, at 1172.

75. See 34 C.F.R. § 106.41(b) (2009) (“[A] recipient may operate or sponsor separate teams for members of each sex where selection for such teams is based upon competitive skill or the activity involved is a contact sport. However, where a recipient operates or sponsors a team in a particular sport for members of one sex but operates or sponsors no such team for members of the other sex, and athletic opportunities for members of that sex have previously been limited, members of the excluded sex must be allowed to tryout for the team offered unless the sport involved is a contact sport." (all emphasis added)).

76. See supra note 35.

77. See, e.g., Clark v. Ariz. Interscholastic Ass'n, 695 F.2d 1126 (9th Cir. 1982) (holding that excluding boys from playing on girls' volleyball teams was not a violation of the equal protection clause because the policy's purpose was to promote opportunities for girls and to remedy past discrimination); Kleczek ex rel. Kleczek v. R.I. Interscholastic League, Inc., 768 F. Supp. 951, 956 (D.R.I. 1991) (denying injunctive relief, in part, because plaintiff was unlikely to be successful on the merits of his Equal Protection claim where excluding male student from girl's field hockey team was unlikely to be a violation of the Equal Protection Clause); see generally Daroski, supra note 64, at 153.

78. While the Supreme Court has interpreted the EPC as allowing girls to try out for boys' teams, the reverse is not true. This seemingly inequitable distinction on its face may be attributed to the different rationales at play. Most courts have permitted girls to try out for boys' teams, but not the reverse, because increasing athletic opportunities for girls, as well as redressing past discrimination against them, are strong justifications that are not a concern when boys assert similar rights. See, e.g., Clark, 695 F.2d 1126. 
instigate more debate on the status of male athletes and the quest to identify and promulgate a "better" high school athletic system. ${ }^{79}$

This note will briefly outline some of the more popular alternatives and focus particularly on a proposal that has not received much serious discussion, although it is often mentioned in passing as an alternative to pure sexsegregation: height/weight requirements as a facially non-discriminatory system of athletic separation.

\section{Part III. Moving Past IX's Contact Sports Exception: The Good, the Bad, and the Popular Alternatives to the System}

\section{After CSE Elimination}

\section{A. Separate Probably Cannot Be Equal, but Is Full Integration Practical?}

A close cousin to the CSE debate, Title IX's provision allowing for sexsegregated sports has also taken a considerable amount of abuse from scholars. ${ }^{80}$ The elimination of sex-segregated sports and full integration would of course nullify the CSE. This is an attractive proposal in that it comports both with already-accepted notions in other branches of the law that separate can never be equal, ${ }^{81}$ and with cultural preferences for obtaining positions by way of merit. ${ }^{82}$ Additionally, there may be some danger in keeping the concept of separate but equal alive. Several articles arguing for sex-segregated public education draw support from Title IX's endorsement of it in the sports context. They use its existence in one part of the law to reinforce gender stereotypes in other areas. ${ }^{83}$

The downside to eliminating sex-segregated teams is that it could substantially reduce the number of athletic opportunities afforded to women.

No matter how hard feminist theorists try, they cannot eliminate the identifiable

biological differences between men and women simply by saying that they do not

79. See supra note 78.

80. See, e.g., Robinson, supra note 8 , at 340.

81. Notably, Brown v. Bd. of Educ., 347 U.S. 483, 495 (1954).

82. See Robinson, supra note 8, at 339,351-53 (arguing for sex integration when equal opportunity cannot be realized and evaluating a proposal in which "skill would become the only qualification for positions on teams").

83. See Rebecca A. Kiselewich, In Defense of the 2006 Title IX Regulations for Single-Sex Public Education: How Separate Can Be Equal, 49 B.C. L. Rev. 217, 254-60 (2008). See also Diane Heckman, Title IX Marks Its 35th Anniversary by Opening the Doors to Single-Sex Public Elementary and Secondary Schools, 237 ED. LAW REP. 1, 14-16 (2008) (describing the 2006 Title IX Regulations allowing for singlesex public schools, classes and non-athletic extracurricular activities). 
exist. Since the biological differences of strength and speed are the foundation upon which many sports are built, gender equality through assimilation cannot be achieved unless contact sports radically alter their structure. ${ }^{84}$

Whether the differences we perceive between men and women are largely nurture or largely nature, where separate cannot be equal, the most just system in theory is a fully integrated system. As long as we attach significance to differences in gender as it relates to opportunity, we will forever be dissatisfied because we will never attain equality. Ideally, society will advance over time to a point where it ceases to make such a huge distinction between the sexes and comes to view sex, like race, as immutable. Practically, this will not occur, if at all, anytime soon and so a more practical solution is one that moves society past the CSE temporarily and aims for more idealistic goals in the future.

\section{B. Replacing the CSE and an Evaluation of Alternatives}

One alternative to the current system is to keep sex-segregated teams intact, but allow only "exceptional" females to play on boys' teams. ${ }^{85}$ This proposal could be understood as similar to the result under EPC jurisprudence. Female athletes may use the EPC to enforce their right to try out for a team in some situations, not for a spot on the team itself. Thus, it is possible that only a limited number of females will ultimately earn a spot on the boys' team. Although this proposal can be interpreted to jibe with the EPC, it might also limit the rights of female athletes under the EPC. What does it mean to be "exceptional" as a female athlete? This label is troublesome, as it suggests that most women should not be permitted to or are not able play with men, reinforcing stereotypes about women in athletics. ${ }^{86}$

84. Furman, supra note 17, at 1185-86 (criticizing the "gender-blind" meritocracy approach) (citations omitted); see also George, supra note 45, at 1144 ("Generally, the physiological distinctions between men and women will assert themselves by high school and certainly college. While we surely are long past any assumptions about 'all' boys being superior athletes compared to 'all' girls, it is nonetheless likely that any football, basketball, or track team selected based on competitive tryouts would be largely, if not exclusively, male." (citation omitted)); Hershtal, supra note 16, at 681 (noting that separate but equal has been justified by several reasons: physical and psychological differences between the sexes, and promoting athletic opportunities for women through the use of separate teams because, impliedly, if not for separate teams, men might dominate women's sports teams).

85. Croudace \& Desmarais, supra note 53, at 1456.

86. See supra notes 8,15 . This solution also fails to address whether it applies equally to girls who have a girls' team they could play on. If not, then it might not even provide the same rights as the Equal Protection Clause, although technically expanding the rights of female athletes under Title IX. 
Another problem with this proposal, which has already arisen when school districts have unilaterally allowed women onto men's teams, is what to do with men who seek to play on women's teams..$^{87}$ As previously stated, the courts have different rationales in Equal Protection jurisprudence for allowing women, but not men, to play on the opposite sex's sports team and their position is certainly defensible. ${ }^{88}$ However, the idea of allowing women but not men to cross-compete seems to offend commonly-held societal notions of fairness, and male students have taken this position in taking their game to the courts. ${ }^{89}$

Another proposal was coined by its author as, "Women Play Men-Sometimes, Women Play Women, Men Play Women-Sometimes." 90 Under this proposal, the opportunity for a man or a woman to try out for the opposite sex's team would depend on whether that team had advantages or notoriety not enjoyed by their own sex's team. ${ }^{91}$ For example, if an organization's women's volleyball team had a thriving program, national attention, and many scholarship opportunities, whereas the analogous start-up men's team had less funding and little-to-no national attention, a man would have the right to try out for the women's team..$^{92}$ In this way, two of the unequalizers of sex-segregated teams in a Title IX regime - traditionally, greater scholarship opportunities and notoriety for men's teams — are dealt with while limiting the possibility of men ousting women from their own teams. ${ }^{93}$

87. See generally Clark v. Ariz. Interscholastic Ass'n, 695 F.2d 1126 (9th Cir. 1982) (holding that excluding boys from playing on girls' volleyball teams was not a violation of the equal protection clause because the policy's purpose was to promote opportunities for girls and to remedy past discrimination); Kleczek ex rel. Kleczek v. R.I. Interscholastic League, Inc., 768 F. Supp. 951,956 (D.R.I. 1991) (denying injunctive relief, in part, because plaintiff was unlikely to be successful on the merits of his Equal Protection claim where excluding male student from girl's field hockey team was unlikely to be a violation of the Equal Protection Clause).

88. See supra note 78.

89. See, e.g., Clark, 695 F.2d 1126; Kleczek, 768 F. Supp. at 956; see also Williams v. School Dist., 799 F. Supp. 513, 517 n.4 (E.D. Pa. 1992), rev'd, 998 F.2d 168 (3d Cir. 1993) ("Obviously, therefore, the defendant uses a 'double standard,' based on gender, in applying Title IX to its sports teams. It is doubtful whether such blatantly unequal application of the same regulation to boys and girls is lawful."); id. at 519 ("Thus, we conclude that with respect to Liberty High School, providing a remedy for past discrimination against girls in athletics does not presently constitute a government interest important enough to justify the current and continuing policy of prohibiting male students from trying out and playing for designated girls' teams when no comparable boys' team is offered.").

90. Robinson, supra note 8, at 353-56.

91. $I d$.

92. $I d$.

93. See supra note 84 . 
Other possible proposals include complete sex integration, where the rules are adjusted to require female participation. ${ }^{94}$ This type of proposal addresses the fact that most sports, especially contact sports, were designed to meet men's strengths by attempting to equalize "the playing field" and by requiring full participation by women. ${ }^{95}$ On the other hand, adjusting the rules of a game can create perverse incentives and distort the way the game is played. ${ }^{96}$

Another scholar suggests that the very nature of high school sports is to supplement the education of children and, with that focus in mind, a 50/50 approach should seem less offensive to our social norms regarding athletic competition. ${ }^{97}$ This approach would place boys and girls on one team, but would still maintain sex segregation with regard to actual competition. ${ }^{98}$ In this way, the separate-but-unequal funding problems are no longer a concern, and the questions about the relative strengths and inherent physical ability of each sex as compared to one another are avoided. ${ }^{99}$

Another similar approach also calls for a 50/50 split of boys and girls. However, this proposal would require a team to have half of the total players on the field be women, and half be men with each sex receiving equal playing time. ${ }^{100}$ Problems with both approaches are that, inevitably, with only one team per school, significantly fewer students will have the opportunity to participate in extra-curricular sports. ${ }^{101}$ Similarly, the "Components Approach" would consist of two groups of players on one team, competing in every event with the outcome of the match dependent on the joint performance. ${ }^{102}$

94. As an example, the author of this note personally participated in an over-22 co-ed soccer league at the Sewickley Sportrak in Sewickley, Pennsylvania. During indoor soccer matches, the league required that a female teammate "touch" the ball within the red line on the opponent's side in order for a goal by that team to count. This author wanted to present all possible options to her readers, but strongly disfavors such an approach, as first-hand experience has taught her that this kind of adjustment to a game creates unanticipated incentives that distort the sport. For example, if only one girl is on offense with two males, the defenders on the opposing team can stop marking the male offenders in possession of the ball to surround the lone female in order to prevent her from "touching" the ball and validating the goal. This result is frustrating to an athlete perfectly capable of participating in the goal in her own right.

95. Robinson, supra note 8 , at 346 .

96. See supra note 94.

97. Furman, supra note 17, at 1188-89.

98. Id.

99. Id. at 1188-94.

100. George, supra note 45, at 1111-12.

101. Id. at 1150; Furman, supra note 17, at 1188-94.

102. Furman, supra note 17, at 1189. 
Other possibilities include developing new gender-neutral sports. ${ }^{103}$ This approach would eliminate the aforementioned bias in the rules of male-created contact sports. ${ }^{104}$ Another is to have three teams: two for each sex and one based on merit. ${ }^{105}$ While this avoids reduction in women's opportunities by not advocating full sex-integration, it calls into question a school's ability to fund three teams, considering that many school districts have trouble just funding two for each sport. ${ }^{106}$ Similarly, there is a concern that this would decrease the level of competition for those left on the segregated teams because the most talented pool of players would be on the sex-integrated team. This would leave very little talent, in the opinion of some commentators, on the women's team because it has a less talented pool to draw from to begin with. ${ }^{107}$

The implementation of a simple quota system, ${ }^{108}$ maintaining the status quo temporarily as society moves towards a better understanding of integration, ${ }^{109}$ and eliminating the rights of a school district to allow opposite sex players to try out for different teams ${ }^{110}$ are also solutions that have been suggested by commentators as alternatives to the current system.

\section{The Possibility of a Height/Weight Standard to Be Applied Equally to}

Boys and Girls Seeking to Try out for an Opposite Sex Contact Sports

Team

One alternative system of athletic segregation that is often mentioned, but rarely discussed in great detail, is a system that considers only objective, nonsex factors such as speed, size, or strength in separating athletes into different sports teams. ${ }^{111}$

As a first step toward a system based on objective, non-sex factors, this note suggests the possibility of maintaining separate teams for boys and girls initially, but allowing girls that are above average weight and height in their age group to try out for a boys' contact sports team where there is a girls' team for the same sport. Similarly, boys below the average height and weight for

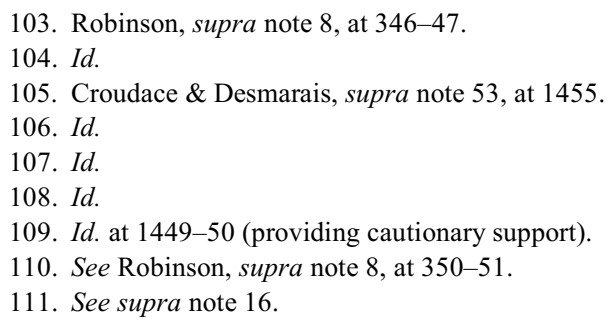


their age group would be permitted to try out for the girls' team. Where a school did not fund a sports team for each sex, athletes would have an unlimited right to try out for the opposite sex's team. For example, where there is no girls' football team, a girl would have the right to try out for the boys' team without any limitation. ${ }^{112}$

A first step past the CSE and its offensive, broad-based exclusion of women based only on sex is one that begins to allow women, if they met an objectively set height/weight requirement, ${ }^{113}$ to try out for a boys' contact sports team and become part of the team if they possess the necessary skills and ability. ${ }^{114}$ The advantage to this proposal, as compared to Title IX's regulations, is that it deemphasizes perceived differences between the sexes by moving towards integration and by applying the same rules to both male and female athletes. Importantly, this proposal also somewhat neutralizes the safety argument so often raised by school districts in the past. ${ }^{115}$ In addition, it avoids the problem encountered by so many of the aforementioned proposals ${ }^{116}$ of boys invading what were once exclusively "girls' teams" and undoing the opportunities Title IX has made available to girls. ${ }^{117}$ The proposal avoids this problem by limiting the eligibility of boys for cross-team participation. Again, this kind of system would more smoothly transition our

112. See supra pp. 19-21. This is similar to, but not exactly the same, as the result under Title IX once the contact sports exemption is eliminated. Title IX also requires that an athlete seeking to try out for the opposite sex's team be a member of a sex that previously had limited opportunities to participate in the sport. See 34 C.F.R. § 106.41(b) (2009). On this basis, courts normally deny male athletes the right to try out for female sports teams under Title IX. See supra note 78.

113. See supra notes 63,64 . Although this note concluded that school districts often discriminatorily use safety justifications as a basis for sex-segregation, it also stated that safety would be a factor to consider when moving forward, as opposed to the sole basis for exclusion. See supra pp. 15-16.

114. The Prince George's County Boys and Girls Club provides rules by which males and females are placed on teams based on age and weight for youths between the ages of 7 and 16 for tackle football. About PGCBGC Football, http://www.leagueathletics.com/Page.asp?n=9333\&snid=408591238\&org= pgcbgcfootball (last visited May 22, 2010). See also email from Calvin Massie, Executive Dir., Prince George's County Boys \& Girls Club, Lanham, MD to author (Jan. 5, 2009) (on file with author) ("[W]e allow girls to play on the same athletic teams as the boys or they can play on separate all-girls teams. If a female participates with the boy teams, then they are evaluated under the same criteria as the boys. But boys cannot play on the girl teams. For football we use a weight and age chart to form teams and the girl standards are the same as the boys." (emphasis added)); but see Croudace \& Desmarais, supra note 53, at 1457 (criticizing this approach).

115. Even though Equal Protection Clause jurisprudence lends little credence to the safety justification, private institutions are still otherwise free to create policies excluding females based on safety because they are otherwise protected by Title IX's contact sports exception. See supra pp. 5-9, 19-21.

116. See infra p. 27. Pertinently, proposals for full sex-integration and for separating teams based solely on non-sex criteria.

117. Furman, supra note 17, at 1185. 
current system to one that deemphasizes sex as an eligibility factor and focuses more on the abilities of the individual.

Like any proposal, this one has its disadvantages. One might counter that imposing objective criteria, like height and weight requirements, serves to merely translate de jure sex discrimination into de facto sex discrimination, because girls of above average size are still less likely to make a boys' contact sports team than boys of below averages sizes are to make a girls' team. First, this proposal is only meant to be a step in the right direction and in that sense, a limited amount of de facto segregation is preferable to Title IX's current de jure bar. Further, society is comfortable with de facto results that limit women in other areas. For example, under Title VII, certain types of occupations may establish standards that effectively preclude many women from qualifying. ${ }^{118}$ Although the objective factors may still limit some women from trying out for boys' teams, this proposal is a step in the right direction since more women than allowed under Title IX will qualify to try out.

Another issue, which is neither unique to this proposal nor the other options noted supra, is why this proposal should be adopted at all since it arguably gives girls, at the very least, fewer opportunities then what they are likely entitled to receive under the EPC. However, as noted above, Equal Protection jurisprudence is less clear on the issue of whether girls can try out for boys' teams when a comparable girls' team is offered. ${ }^{119}$ If this proposal were implemented, it would enhance the rights of female athletes attending private institutions, because this proposal is much broader than what Title IX alone permits. ${ }^{120}$ This proposal would also ease the burden on female athletes at public institutions, as smaller numbers would have to enforce their Equal Protection rights. ${ }^{121}$

Another concern associated with, for example, allowing boys without their own volleyball team unlimited try-outs for the girls' teams, would be the probable result of boys largely displacing girls on these teams. Arguably, this result is unlikely, as a significant amount of boys' interest and support in

118. See 42 U.S.C. $\S 2000 \mathrm{e}-2(\mathrm{e})(1)$ (providing for sex as a bona fide occupational qualification); Lanning v. SEPTA, 181 F.3d 478, 490 (3d Cir. 1999) (noting disparate impact is legitimate where the job requirement is reasonably related to the position and consistent with business necessity).

119. See supra pp. 8-9 (noting the limitations of the Equal Protection Clause).

120. See supra pp. 19-21 (noting that Title IX does not establish any right for a female athlete to try out for even a boys' non-contact sports team where a girls' team is provided).

121. See supra pp. 8-9 (noting that female athletes must enforce their Equal Protection rights in court). 
volleyball may obligate a school district to create a separate boys' volleyball team. ${ }^{122}$

Although there are disadvantages to this proposal, and implementation of a height/weight requirement has been dubbed "difficult to devise," 123 it makes sense as a small step toward a system of athletics that does not continue to reinforce sex differences and harm women's opportunities to advance in athletics. Women who meet certain objective standards, and who possess the requisite level of athletic ability to make a boys' team, can enjoy the benefits that come from playing on certain male sports teams, such as greater opportunity for scholarships and recruitment. Importantly, allowing boys similar rights is not just for their benefit; placing less emphasis on sex differences by way of objective, non-sex factors helps move society past preconceived notions about the athletic ability of girls. Although this proposal initially keeps sex-segregated teams in place, our athletic system can begin to move past sex and focus more on each individual's ability, thereby expanding opportunities for women in sports, which is consistent with the underlying purpose of the statute. ${ }^{124}$

\section{Part IV. Why Is the CSE Still Around?}

Nine years ago, one author speculated that perhaps the climate of female sports sensations - the WNBA, Women's Ice Hockey Olympic recognition, and US Women's Soccer World Cup, to name a few-would create enough political momentum that the CSE would be eliminated. ${ }^{125}$ Not only has this political pressure not occurred, but a trend toward related single-sex education shows that rather than breaking down gender stereotypes, we are embracing them. ${ }^{126}$ Similarly, it does not seem likely that the Supreme Court will

122. See supra note 28.

123. Petrie v. Ill. High Sch. Athletic Ass'n, 394 N.E.2d 855, 862 (Ill. Ct. App. 1979).

124. See Equity in Athletics Inc. v. U.S. Dept. of Educ., 291 Fed. Appx. 517, 523 (4th Cir. 2008) (citing a litany of case law describing the goals of Title IX as equalizing opportunities between men and women as groups, stating required program expansion for the under represented sex is one goal of the statute).

125. Sangree, supra note 17 , at $384-85$.

126. Kiselewich, supra note 83, at 219 (discussing DOE Title IX regulation amendments that expanded the ability of public elementary and secondary schools to provide single-sex educational opportunities); see also id. at 219-20. Most disturbingly, this author is not alone in arguing for "separate but equal" education by analogizing it to our societies" socially-acceptable "separate but equal" public school athletic system. Id. at 220-21, 254-60. 
invalidate the CSE as unconstitutional anytime soon, as it has consistently denied certiorari. ${ }^{127}$

Part of the problem is the lack of opposition to the CSE from females. ${ }^{128}$ In line with that reasoning, there is a disconnect between what scholars consider an archaic or old-fashioned notion and what society-namely, those who vote-considers archaic or old-fashioned. ${ }^{129}$ Many of the stated justifications for upholding the CSE are laughable to academics. ${ }^{130}$ No matter how often law review articles cite the debate over the CSE, comment that elimination is "obviously needed," 131 and assert no further debate is necessary, this is simply not true. Protectionism is still generally accepted by the public. A specific example of this is that, as of the 2008 cross country season, eleven states still prohibited girls from competing over the same distances as their male peers. ${ }^{132}$

Many of the initial justifications for the CSE contribute to its continued existence. For example, initial generalizations that all women could not compete physically with men created barriers for women wishing to participate in male-only sports. But as another author on the subject eloquently put it,

This is really the wrong question. The right question is whether there are any women who can compete on the level that men are on. Are all of the best, fastest and strongest men faster, better and stronger than the best, fastest, strongest women? Is there a woman better, faster and stronger than the weakest male player on a given team? ?33 $^{133}$

Some members of society have moved a step beyond this archaic way of thinking; accepting that there are some women who may be capable enough to compete with men. Despite this, there still subsists a subtler perception that only exceptional females can compete on the same level as men in any sport,

127. Id. at 255 .

128. Robinson, supra note 8 , at 323 ("Women may fear that if girls get to play on boys [sic] teams, then boys will get to play on girls [sic] teams; that if girls [sic] teams are replete with boys then fewer opportunities for girls exist; and that if total integration occurred, girls [sic] teams would disappear. Also, even women harbor 'traditional notions' about differences between boys and girls. For women also, there is a distinctive efficiency concern.").

129. See Furman, supra note 17 (describing his belief that CSE elimination is an easy conclusion as compared to the persistence of protectionist justifications for sex discrimination).

130. See id.

131. Id.

132. Little, supra note 15, at 712. Little argues that this evidence could also be attributable to the fact that school districts believe that if they lengthen the distance, fewer girls will participate in the sport.

133. See Robinson, supra note 8, at 346. 
especially contact sports. ${ }^{134}$ This perception perpetuates a false sense of satisfaction with the standing law. Scholars have long argued that the CSE should be eliminated because regardless of men's supposed athletic and physical superiority, the duty to treat women, including exceptional female athletes, as individuals makes an overall bar inappropriate. ${ }^{135}$ The perception that competitive female skill is not necessarily common and the notion that only a small number of women are able to compete with men is held by many. ${ }^{136}$ By focusing arguments on only the rights of the exceptional to play with the "big boys," academia reinforces these social beliefs. ${ }^{137}$ Hopefully, both the research in this note and young women like Angela Kost have apprised the reader that co-ed competition is not just reserved for the rare female athlete who can compete with men, but that it is becoming more common as schools unilaterally permit girls to participate in men's sports and as girls utilize, when possible, their rights under the EPC.${ }^{138}$ It is elitist at best, and foolish at worst, to assume that protectionism is antiquated, archaic, and no longer at issue in the context of female athletics. ${ }^{139}$

134. Id. ("Is there a woman better, faster and stronger than the weakest male player on a given team? Although fewer, there are such women."); see also posting of Cody C. to SerendipUpdate's Blog, http://serendip.brynmawr.edu/exchange/node/1753?page=1 (Feb. 3, 2009, 22:01) (last visited May 22, 2010) ("I am not saying that some girls aren't as athletic as guys, but MOST aren't") (representing a portion of the public's opinions on the subject).

135. Many law review articles cite this as a justification against the CSE and therefore avoid questions about physical superiority as a sex. See, e.g., Robinson, supra note 8, at 346-47; see also Furman, supra note 17, at 1187 ("The concept that women should be able to try out for men's teams and be judged by their skill level is so basic to our understanding of discrimination that it is surprising that the CSE still exists.").

136. See, e.g., Robinson, supra note 8 , at 350 (referencing women that are at least better than the worst man on a team, "I believe there are such women; not enough to expect complete integration, not enough to mandate quotas, but enough to make this whole discussion worthwhile.").

137. To the contrary, many girls are physically capable of competing with boys. See SerendipUpdate's Blog, http://serendip.brynmawr.edu/exchange/node/1753 (containing hundreds of postings by middle school and high school-aged girls playing contact sports on boy's teams); see also George, supra note 45, at 1147 ("According to the National Association of State High School Associations, 779 girls played high school football in the fall of 2000, and the National Football League reports that 1.3 million girls competed in its annual Punt, Pass, and Kick competition last year."). Keep in mind this is the number of lucky, capable girls who managed to find a school district that would allow them to play, even while legally not obliged to. See also supra notes 4-6 (listing even more girls playing hockey and wrestling with boys).

138. See Lantz ex rel. Lantz v. Ambach, 620 F. Supp. 663 (S.D.N.Y. 1985) (holding that female athlete prevented by analogous state regulation to the CSE had her Equal Protection rights violated and enjoined state officials from enforcing the regulation).

139. See, e.g., Angela Onwuachi-Willig, Book Review, GIRL, Fight, 22 Berkeley J. Gender L. \& JUST. 254, 255-56 (2007) (noting that for today's twenty and thirty-something year old women, "feminism has become a bad word-the new 'F' word."). However, there is also hope and a lot of excitement among 


\section{Moving Past the CSE: Conclusion}

The primary purpose of this note was to advocate elimination of the CSE and to discuss the state of the law after elimination, as well as proposed alternative athletic systems. The CSE, while severely criticized in this note and by others, still currently discriminates against women based only on sex. In researching this note, the author came across many stories about girls and young women attempting to or successfully participating in contacts sports with men. Hopefully, this information helps dispel any qualms a reader might have about the timeliness of this issue as none of these female athletes actually has the right to play contact sports with males under the Title IX regulations. Rather, their right to play depends on the discretion of individual Title IX private entities or, if they fortuitously attend a public institution, their ability to enforce their rights under the EPC. Despite many scholarly articles on the subject predicting change, the status quo remains and the reasons for this need to be more deeply examined. In moving past the CSE, the public, and specifically student-athletes, need to be made fully aware of the importance of this section of the law. Hopefully, the inspirational stories of these young female athletes will translate into political action as they grow older.

middle school and high school-aged girls already playing on boys' contact sport teams. Hopefully their beliefs, enthusiasm, and experiences will culminate in political action later in life. For example, this young woman writes, "I think that girls should be equal to guys. I'm in 8th grade and am looking 4 a highschool. [sic] So far I've found out that some of the high schools that [are] in my area will let me play foot ball. [sic] And I am soooooo excited to try out next year." Posting of Rachel to SerendipUpdate's Blog, http://serendip.brynmawr.edu/exchange/node/1753?page $=2$ (Feb. 6, 2008, 11:07) (last visited May 22, 2010). See also postings of various individuals to InfoSports: Girls in Football, http://www.infosports.com/ football/5.htm (last visited May 22, 2010). 